\title{
Women in Advertisements: Women or Objectified Thin Bodies?
}

\author{
Bocage Barthelemy Yvana $^{1 *}$, Houtin and Laurene ${ }^{1,2}$ \\ ${ }^{1}$ Laboratoire Parisien de Psychologie Sociale Université de Paris-Nanterre, France
}

${ }^{2}$ Ad Hoc Lab, France

*Corresponding author: Yvana Bocage Barthélémy, Laboratoire Parisien de Psychologie Sociale Université de Paris Nanterre, France

\begin{abstract}
Since the beginning of Humanity history, women are one of the main focuses of attention. Women have to deal with beauty standards which are dynamic and are changing over time. Thus the actual beauty standard is very thin: to be beautiful, women have to be very thin. But women bodies in ads are retouched and unrealistic. Hence, when women with real bodies are confronted to thin-ideal bodies, they are, in fact, confronted to an unattainable standard of women beauty. By now, many findings suggest that repeated exposure to such unrealistic standards have negative and significative implications on women. Some of these effects could certainly be avoided if individuals, and especially women, were better informed about the unrealistic and harmful nature of this norm and its consequences.
\end{abstract}

Keywords: Objectivation; Thin Ideal; Advertisements; Women

\section{Introduction}

Since the beginning of Humanity history, women are one of the main focuses of attention. They have a lot of duties; have to adopt specific behaviors and to be good mothers and good wives. Specifically, women's bodies are, since several decades, in the spotlight too. Women have to deal with beauty standards which are dynamic and are changing over time. With the apparition of mass media, the social pressure doesn't only come from pairs and parents but also from media [1]. By now, mass media is considered as the most powerful and persuasive source of influence [2-4] as they are constantly surrounded by advertisements even when we do not necessarily pay much attention to Most ads (whatever the promoted product) use women bodies which depict the ideal norm of feminine beauty. Women in ads are presented as perfect, thin, beautiful, with smooth skin, very white teeth and unrealistic measurements [5]. Since the 1980s to the 1990s, we observe a significant decrease in the weight of female models [6] as models are now mostly underweight. Thus the actual beauty standard is very thin: to be beautiful, women have to be very thin. But women bodies in ads are retouched and unrealistic. Hence, when women with real bodies are confronted to thin ideal bodies, they are, in fact, confronted to an unattainable standard of women beauty. By now, many findings suggest that repeated exposure to such unrealistic standards have negative and significative implications on women. By setting what is appreciable or desirable in a woman [7], standards provide women with indicators to assess their own bodies. Social comparison with the weight standard contributes to the construction of women's image of their own bodies [8] and since the standard is excessively thin , many women overestimate their weight, and even perceive themselves as overweight when they are objectively not [9]. Moreover, a perception of excess weight lead women to suffer from "normative discontent" [8] and a body dissatisfaction $[10,11]$ which can affect women's quality of life by generating low self-esteem [12], anxiety and even depression [13] and a greater accessibility of suicidal thoughts [14]. It also generates negative behavioral consequences: women who are dissatisfied with their bodies tend to use fast, harmful and unhealthy weight loss eating and physical practices [15], and weight overestimation predicts the use of behaviors that lead individuals to gain weight [16-19].

\section{Conclusion}

In addition, the thinness standard makes overweight synonymous with normative deviance. People who are overweight are the target of stereotypes: they are suspected of eating in secret, refusing to control their diet, losing control of themselves when eating, and over-consuming [20-22]. Overweight women are specifically considered as not being feminine and sensual [23]. Moreover, overweight individuals experience significant stigmatization [23-25] which obviously affects their quality of life and food behaviors. It also may also lead women who perceive themselves as overweight to make poor food choices and to consume more fatty and sweet 
foods through stereotype threat $[25,26]$. Some of these effects could certainly be avoided if individuals, and especially women, were better informed about the unrealistic and harmful nature of this norm and its consequences. Unfortunately, only a few are. We believe that public policies should address this limit and provide women the key elements to limit the negative consequences of exposure to the slimming standard, particularly in advertising.

\section{References}

1. Triggerman M (1992) Body size dissatisfaction: Individual differences in age and gender, and relationship with self-esteem. Personality and Individual Differences 13(1): 39-43.

2. Groesz LM, Levine MP, Murnen SK (2002) The effect of experimental presentation of thin media images on body satisfaction: A meta analytic review. International Journal of Eating Disorders 31(1): 1-16.

3. Heinberg LJ (1996) Theories of body image disturbance: Perceptual, developmental, and sociocultural factors. Body image, eating disorders, and obesity: An integrative guide for assessment and treatment p: 27-47.

4. Neumark Stanier D, French SA, Hannan PJ, Story M, Fulkerson JA (2005) School lunch and snacking patterns among high school students: associations with school food environment and policies. International Journal of Behavioral Nutrition and Physical Activity 2(1): 14.

5. Mazur A (1986) US trends in feminine beauty and over adaptation. Journal of Sex Research 22(3): 281-303.

6. Thompson JK, Heinberg LJ, Altabe MN, Tantleff Dunn S (1999) Exacting beauty: Theory, assessment and treatment of body image disturbance. Washington DC: American Psychological Association.

7. Amadieu JF (2002) Le poids des apparences : Beauté, amour et gloire. Odile Jacob.

8. Dany L, Morin M (2010) Image corporelle et estime de soi: extrude auprès de lycéens française. Bulletin de psychologie 2(5): 321-334.

9. Ziebland S, Robertson J, Jay J, Neil A (2002) Body image and weight change in middle age: a qualitative study. International journal of obesity 26(8): 1083.

10. Cash TF, Green GK (1986) Body weight and body image among college women: Perception, cognition, and affect. Journal of personality assessment 50(2): 290-301.

11. Williamson DA, Gleaves DH, Watkins PC, Schlundt DG (1993) Validation of self- ideal body size discrepancy as a measure of body dissatisfaction. Journal of Psychopathology and Behavioral Assessment 15(1): 57-68.

12. Chatard A, Selimbegović L (2011) When self-destructive thoughts flash through the mind: Failure to meet standards affects the accessibility of suicide-related thoughts. Journal of Personality and Social Psychology $100(4): 500-587$.

13. Sypeck MF, Gray JJ, Ahrens AH (2004) No longer just a pretty face: Fashion magazines' depictions of ideal female beauty from 1959 to 1999. International Journal of Eating Disorders 36(3): 342-347.

14. Brug J, Wammes B, Kremers S, Giskes K, Oenema A (2006) Underestimation and overestimation of personal weight status: associations with socio-demographic characteristics and weight maintenance intentions. Journal of Human Nutrition and Dietetics 19(4): 253-262.

15. Duong HT, Roberts RE (2014) Perceived weight in youths and risk of overweight or obesity six years later. Journal of psychosomatic research 76(1): 23-27.

16. Duong HT, Roberts RE (2016) Discordance between measured weight, perceived weight, and body satisfaction among adolescents. Journal of psychosomatic research 88: 22-27.

17. Puhl RM, Heuer CA (2009) The stigma of obesity: a review and update. Obesity 17(5): 941-964.

18. Friedman KE, Ashmore JA, Applegate KL (2008) Recent experiences of weight-based stigmatization in a weight loss surgery population: psychological and behavioral correlates. Obesity 16(S2): S69-S74.

19. Puhl R, Brownell KD (2001) Bias, discrimination, and obesity. Obesity research 9(12): 788-805

20. Puhl R, Latner J (2008) Weight bias: New science on an significant social problem. Obesity $16(\mathrm{~S} 2)$ : S1-S2

21. Griffin AW (2006) Women and weight-based employment discrimination Cardozo, Journal of psychology.

22. Andreyeva T, Puhl RM, Brownell KD (2008) Changes in perceived weight discrimination among Americans, 1995-1996 through 2004-2006. Obesity 16(5): 1129-1134.

23. Houtin L (2018) La menace du poids idéal: effets de la menace du stéréotype sur les choix et la consommation alimentaires de jeunes femmes se percevant en surpoids. Doctoral dissertation, Paris Nanterre University 13: 631.

24. Malkin AR, Wornian K, Chrisler JC (1999) Women and weight: Gendered messages on magazine covers. Sex Roles 40(7-8): 647-655.

25. Ricciardelli LA, McCabe MP, Banfield S (2000) Sociocultural influences on body image and body change methods. Journal of Adolescent Health 26(1): 3-4.

26. Stice E, Mazotti L, Krebs M, Martin S (1998) Predictors of adolescent dieting behaviors: A longitudinal study. Psychology of addictive behaviors 12(3): 195 .

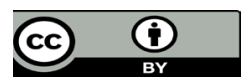

This work is licensed under Creative Commons Attribution 4.0 License

To Submit Your Article Click Here: Submit Article

DOI: $10.32474 /$ SJPBS.2019.02.000151

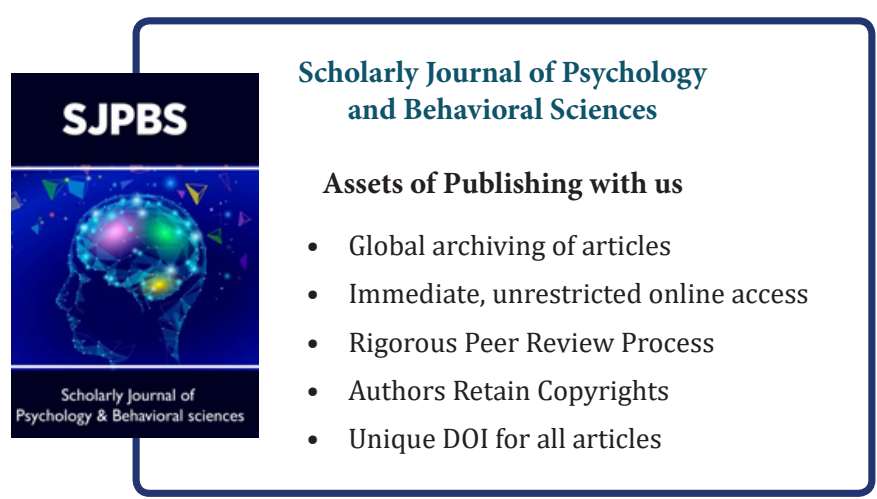

